\title{
SUMPTUOUS FEASTING IN THE ANCIENT NE AR EAST: EXPLORING THE MATERIALITY OF THE ROYAL TOMBS OF UR
}

\author{
Louise Steel
}

Summer bowed to Winter and offered him a prayer. In his house he prepared emmerbeer and wine. At its side they spend the day at a succulent banquet. Summer presents Winter with gold, silver and lapis lazuli. They pour out brotherhood and friendship like best oil.

(The Debate between Winter and Summer, 310-14, Oriental Institute)

\section{INTRODUCTION}

Luxurious materials, intoxicating drinks and sumptuous foods were the stuff of high status feasts throughout southern Mesopotamia during the third millennium BC (Table 10.1). This chapter examines the materiality of extravagent feasting, focusing on the Early Dynastic period in southern Mesopotamia ${ }^{1}$ and specifically the objects from the Royal Tombs of Ur. It explores the sensual experience of feasting, as evidenced by representations as much as the material objects used to serve and consume food and drink. It scrutinizes the incorporation of enchanted objects (Gell 1992) within the politics of power around the dining table and at the graveside, specifically focusing on the high-end objects used by elites - within what Dietler (1996; 2001) has described as diacritical feasting - as a means of separation, social enhancement, reiteration and legitimization, of their special elevated position in society (cf. Pollock 2003, 18). Furthermore, it investigates the agency and materiality of the substances used to craft these objects and in particular how specific materials were able to evoke a response on the part of the participants in the feast. It will then go on to consider how these objects of feasting not only mediated social relations within a specific social context, but likewise how these were increasingly manipulated to create a mutual language of elite consumption, within a shared cultural milieu (Gosden 2003). 


\section{FEASTS, SOCIAL ADVANTAGE AND POLITICAL POWER}

"'Feasts." The word conjures up images of sybaritic self-indulgence or luxurious, lavish opulence and frivolity'

(Hayden 2014, 2)

Feasts are opulent events - a sumptuous, vibrant display of lavish quantities of highly valued, possibly otherwise restricted, food and drink, which the host shares out amongst the participants in a fest of extravagant consumption. The political significance of feasting, in particular within the context of early state societies, has received considerable attention (Dietler 1996; Dietler 2001; Hayden 2014). Feasts create, foster, maintain and reiterate social bonds within communities. Social relations are mediated through the sharing of food and drink and, as with gifting (Mauss [1925] 1990), individuals are able to gain prestige and status from their largesse and perceived generosity, whilst at the same time binding their guests to them in a network of obligation and reciprocity. The hospitality of the feast is used to forge political, military and dynastic alliances, against a backdrop of conviviality, gift exchanges, entertainment and display. Feasts might also be manipulated by social, political and religious elites to assert hierarchical social structures, demonstrate exclusivity and to legitimize the status quo. In such cases, the exclusive membership of the feasting club will be reiterated by distinctive cuisine (possibly even luxury foods to which taboos and sumptuary laws adhere), elaborate dining equipment, specialized knowledge of social practices, ritual, etiquette (socially acceptable acts, the correct implements to use and ways to handle these (Stockhammer 2012), social knowledge of how to consume foodstuffs) and the distinctive apparel of the feasters (see Dietler 1996; Pollock 2003, 25; Steel 2004, 163-4).

Feasts, however, are more than just a political strategy used to bind communities and to emphasize the power and prestige of the elite. They are also a sensual spectacle, which disrupt daily life cycles and habitual modes of consumption within the household. Feasts represent ' $[t]$ he creation of a trans-corporeal landscape, a landscape that comes alive through the sharing of sensorial effects, of feelings and emotions' (Hamilakis and Sherratt 2012, 194). Hamilakis $(1998,2008)$ argues that the physical, sensory experiences of the feasters (the smells and taste of the food, the touch of the feasting equipment and the sounds of the revelry) are important aspects of embodied, incorporated knowledges (cf. Connerton 1989) 
that play a key role in the creation of social memory. Through the very act of ingesting foodstuffs, alongside the other bodily knowledges integral to the feast, collective/group memories are created and physically 'sedimented onto the participants' bodies... a way of producing embodied history' (Hamilakis and Sherratt 2012, 194). These 'physical memories' foster individual and collective negotiations of identity and thus reinforce the social and political dynamics of a community. We will return to the evidence for the embodied, sensorial experience of the feasters in Early Dynastic Ur later.

\section{EVIDENCE FOR FEASTING IN MESOPOTAMIA}

There is considerable evidence for elite banqueting in Mesopotamia, dating back to at least the late fourth millennium BC. Beginning with the Proto-Cuneiform documents of the Late Uruk period, texts provide significant information concerning centralized control over food production within the temples (and later the palaces). In particular, these refer to cereal processing, beer and bread production and the disbursement of rations (including those for high status officials) (Damerow 1996; cf. Damerow 2012 for details of Sumerian beer production). The significance of these cereal products within Mesopotamian feasting is suitably emphasized by the actual meaning of the word 'banquet' in Sumerian - namely 'the place for beer and wine' (cf. Pollock 2003, 24; this reiterates the weight which Hayden et al., this volume place on the development of cereal processing technologies in relation to feasting practices in the Epi-Paleolithic). An important aspect of economic control over agricultural produce was the provisioning of feasts; feasts which allowed the temple/palace to accumulate wealth in the form of offerings and tribute (Schmandt-Besserat 2001, 398-9). Mythological and royal texts provide the social context for feasting - the investiture of the king, religious festivals celebrating the pantheon of gods, military victories, alliances and diplomatic envoys, as well as major biographical events such as marriage and birth (Schmandt-Besserat 2001, 397; Pollock 2003, 24; Cohen 2005, 83). Numerous scholars have supplemented these texts with reference to the banquet scene (Fig. 10.1-2) - a popular motif in elite Near Eastern art throughout the third-first millennia BC (Collon 1992; Pinnock 1994; Schmandt Besserat 2001, 392-7, figs. 14.1-6; Pollock 2003, 24). The materiality of the banquet, and specifically the objects incorporated within such an activity, have received less attention despite the rich evidence from deposits such as the Royal Tombs of Ur (see however Pollock 2003, 25, 27; 
Cohen 2005, 84-5, 88-92, Appendix D). We shall focus on the material objects used in the feast in more detail below.

$<$ FIGURE 10.1 here $>$

\section{EXPERIENCING THE FEAST}

'Feasting is a theatre of the senses, an arena of high drama, be it the screams of animals to be killed/sacrificed, the streams of blood, the smells of cooking food, or the performative gestures of serving, toasting, eating and drinking, and of ritually disposing of the paraphernalia and remnants of the occasion'.

(Hamilakis and Sherratt 2012, 194)

The banquet scenes on cylinder seals (Fig. 10.2-3) and other high status objects reveal much about the cultural practices embedded in elite feasting and the sensual experiences of the participants. Most representations depict only a small number of participants (two or three seated banqueters and a couple of attendants - this might in part be due to miniature size of the cylinder seals). The Standard of Ur (Hansen 1998, fig. 3b) however, depicts a larger congregation; the principal banqueter is seated on the left side of the upper register (and at a larger scale) facing a row of six seated males. Certainly, archaeological evidence indicates that larger gatherings were common at feasting events. Cohen $(2005,88)$ for example highlights the multiple sets of vessels found in tombs PG1407 and PG755, which he concluded were supplies for communal consumption. This situates some Mesopotamian feasting activity at the graveside, a form of communion with the deceased and the ancestors a ritual which became known as kispum in the second millennium BC (Cohen 2005, 106; MacDougal 2014) These repeated sets of drinking and serving vessels would reiterate the collective identity of the revellers who used this specialized equipment.

$<$ FIGURE 10.2 here>

Feasting was certainly not a gendered activity; several scenes include women, and texts likewise indicate the important role of the queen in these rituals, as the intermediary between the people and the gods (Schmandt-Besserat 2001, 398). The scenes typically depict seated individuals, frequently facing each other, who are drinking what is presumably an 
intoxicating beverage. Animals, either for sacrifice to the gods or to be consumed at the feast, are brought along by servers and attendants in the lower registers, but otherwise the food consumed at a banquet (meats, bread, fruit etc., cf. Pollock 2003, 26) is not typically laden on the tables in front of the revellers (see however the feasting lion on a seal impression from the Seal Impression Strata at Ur, Hansen 1998, fig. 42; also Schmandt-Besserat 2001, 394). From this we might concur with Pollock $(2003,24)$ that, rather than consuming large quantities of foods, Mesopotamian feasting primarily revolved around the consumption of an alcoholic beverage. Ancient texts indicate this to be either beer or wine, likely chosen for its psychoactive properties, expressly to enhance the sensual experience of the participants (cf. Dietler 2001, 73; McGovern 2009, 18-27; see also discussion in Collard, this volume). The tastes and smells of the foodstuffs consumed and the specialized locales for feasting served to reinforce these sensations.

The participants' senses were bombarded by a multitude of other stimuli: the colours, touch, tastes, smells and sounds of feasting. In addition to the inevitable hubbub of feasting - the camaraderie of the revellers, the sounds of the implements and vessels used in serving and consuming victuals, the attendants and servers bringing more food and drink and possibly even the sounds of animals being sacrificed - auditory senses were similarly stimulated by music, singers, dancers, oral recitation, as illustrated by the lyre-player and a possible singer standing behind the final seated figure on the top right register of the Standard of Ur (Fig. 10.1). A similar such lyre to this (the Great Lyre) was famously found in tomb PG789 (Hansen 1998, 53, Cat no. 3; Reade 2003, 97, Cat. no. 52). Other performances included wrestling and unarmed combat (Schmandt-Besserat 2001, fig. 14.4). Visual stimulation of the senses was achieved by the lavish display of food and drink as well as tribute and booty, and possibly also from animal sacrifice, along with the ornaments and clothing of the feasters. The latter is illustrated by the bedazzling array of elaborate items of personal adornment from the Royal Tombs of Ur - headdresses, earrings, diadems, necklaces (Pittman 1998, 91, Cat. no. 29,93 , Cat. no. 30, 95, Cat. no. 31, 99-117, Cat nos. 37-82) and ceremonial weaponry (Weber and Zettler 1998a, 169, Cat. no. 146) to list but a few. These objects give us a hint as to the opulent ceremony and sense of occasion of these banqueting events. 
The embodied experiences of the actors at the banquet were reiterated through their bodily actions; these would manifest themselves via appropriate gestures, posture, etiquette, where to sit/stand and the correct way to handle and use feasting equipment (cf. Connerton 1989; Pollock 2003, 25; Stockhammer 2012). All these actions were culturally situated, shared knowledges, which conveyed messages of status, identity and belonging; as such they served to reinforce the social order through the creation of an exclusive group. Through these repeated embodied actions, and the interplay with the material objects of feasting, the participants of the banquets actively shaped and created their social and material world, personal experiences and identities.

We are able to observe some of the embodied actions of the feasters and revellers in the banquet scenes and correlate these with known artefacts; through this process we can reconstruct the appropriate body knowledges they employed and their haptic engagement with the objects of feasting. The feasters would be seated, a potent symbol of power and authority in the ancient Near East (Feldman 2006, 223), usually facing each other, and would frequently be waited upon by attendants bearing drinks or food. There were different types of drinking equipment - all of which are paralleled with extant archaeological examples - and the images indicate both very different ways in which alcoholic beverages were ingested and how the drinking equipment was handled, reiterating the notion that feasting involved complex modes of culturally informed body knowledges. Interestingly, the feasters invariably hold the equipment in their right hand, which might hint at other socially ingrained taboos and cultural knowledge.

On the Standard of Ur (Fig. 10.1, Hansen 1998, fig. 36b) for example, all the banqueters hold a conical cup in their right hand, which is raised perhaps in a toast. We can identify these drinking vessels with the delicate silver (and one electrum) splayed conical tumblers found in some quantities in Royal Tomb PG800 at Ur (Weber and Zettler 1998, 133-4, Cat nos. 105107) and the associated Death Pit (Zettler 1998, fig. 33). Intriguingly, these objects were all decorated with a eight-petalled rosette motif on the base (Fig. 10.3) where it would not be obviously visible when set down on a surface, only being revealed to a drinking partner when the cup is tipped back whilst the banqueter was drinking (and plausibly when empty and upturned on a table). This raises interesting notions of concealed and revealed knowledges, 
which merit further discussion. ${ }^{2}$ Other modes of drinking and handling of equipment include hemispherical or bell-shaped bowls, which were held cupped in the hand (Schmandt-Besserat 2001, fig. 14.3). These are paralleled at Ur in gold (Weber and Zettler 1998, 128-9, Cat. nos. 97-98), silver (Weber and Zettler 1998, 131-2, Cat. nos. 100-104) and stone (Zettler 1998a, 157, Cat. no. 131, 159, Cat. no. 134). Perhaps the most iconic of the images is that of shared consumption of beer in tall jars, which was drunk through narrow tubes (cf. Fig. 10.2), possibly to avoid ingesting scum or sediment, but also perhaps to intensify the intoxicating properties of the drink. Drinking tubes of copper, silver and gold were found at Ur (Pollock 2003, 25); one gold tube was found still in situ, placed in its silver drinking jar in PG800, the Tomb of Puabi (Weber and Zettler 1998, 139, Cat. nos. 115-116). Attendants are also shown serving liquids from spouted jars or otherwise using these vessels to pour libations (AndréSalvini 2003, 75, Cat. no. 34). This was an ancient form of vessel, attested in luxurious materials from the Late Uruk period (Strommenger 1962, pl. VIa) and crafted in silver in the Royal Tombs of Ur (Weber and Zettler 1998, 136, Cat. no. 110).

\section{$<$ FIGURE 10.3 here $>$}

The diversity of equipment and embodied drinking practices is likely reflected a number of social customs. This might simply be the appropriate choice of vessel for a specific beverage (beer, wine etc.), much as we would distinguish between a disposable Styrofoam coffee cup, a porcelain tea cup, a china mug, a beer tankard, a wine glass or a champagne flute for example. Alternatively, a specific vessel (and the material from which it was made) might refer to social boundaries - gender, status, class, or specific identities (as suggested by Pollock 2003, 27). These are interesting questions to pursue, but lie beyond the remit of this paper. We will however, consider the materiality of the object and in particular the agency of the substances from which it was crafted.

\section{TECHNOLOGIES OF ENCHANTMENT: CRAFTING THE FEAST}

Consumption of exquisite objects crafted from luxurious and exotic materials lay at the heart of the Early Dynastic elite's social and material worlds, as is exemplified by the array of objects found in the Royal Tombs of Ur (cf. Hansen 1998; Reade 2003). We will now explore the materiality of the actual objects from the tombs to better understand how they were 
entangled within the material world of Early Dynastic Ur and used to mediate social relations situated in the dialectics of feasting.

There has been considerable work done on the production of high status, symbolically and ideologically charged objects that were created by attached specialists - the crafting of socially valued and elaborately decorated items which had a badge of exclusivity (Brumfiel and Earle 1987; Helms 1993; see discussion in Steel 2013, chapter 6). These objects were intended to be displayed, used and viewed in highly visual ceremonies, ritual activities and occasions when political power is reified, such as the banquets discussed above. They reinforced elite ideology, for example through the manipulation of esoteric iconography, such as the imagery of human-animal hybrids and animals engaged in very human activities adorning the front panel of the Great Lyre from tomb PG789 (Hansen 1998, 55, detail of Cat. no. 3). The ability and appropriate knowledge of how to use these objects was effectively a badge of membership of an exclusive group within society; thus, these crafted objects served to enhance political/religious authority along with the power and prestige of the elite patrons who commissioned their creation.

One way in which we might consider the materiality of the feasting equipment is as enchanted objects (Gell 1992). The power of the object lies in the skill, expertise and technical knowhow of the craftsman, the ability to achieve an extraordinary transformation of natural substances (such as metals, semi-precious stones, shell) into something special, ornate and symbolically eloquent. The agency of the craftsman lies beyond the abilities and understanding of the viewer; consequently the crafted objects beguile the viewer, such that they might need to explain the object's creation in magical terms; ' $[t]$ he exceptional expertise of the specialist appears to the viewer to demonstrate an almost cosmic power and an ability to control the unknown' (Steel 2013, 159; see also Helms 1993).

Returning to the Royal Tombs at Ur, it is evident that we are looking at the creation of a material world of luxury and performance, one which was common throughout contemporary elites of the mid-third millennium in the wider Near East as part of a shared cultural milieu (Gosden 2003). This is exemplified, for example by the circulation of similar objects into the major urban centres of third millennium Syria, such as the silver vessels from the third 
millennium tombs at Umm el-Marra (cf. Schwartz 2007, 51, figs. 3.9-10). As noted by Spielman $(2002,200)$ 'the aesthetic qualities of socially valued goods captures the way in which the form, color, ornamentation, polish, and tactile qualities of an item compel the viewer to desire it'. Specific materials were chosen for their ability to evoke a visceral and emotional response on the part of the feasters - these were beautiful to look at, inviting to the touch and mysterious, coming from faraway places (Helms 1988) and they were certainly enchanted, beguiling the viewer. As such, we might consider these materials as actants (cf. Bennett 2010) - they have agency and the ability to shape and inform the thoughts, actions and emotions of the people that created and used them. Certainly, the materiality of the accoutrements of feasting - in particular the physical properties of the materials chosen to craft these objects - was of paramount importance to the elites of the Near East and certain materials were especially prized within a shared register of values for their lustrous, iridescent qualities and colour (Winter 1995, 2573-5) as well as the metaphorical associations between specific materials and auspicious characteristics (Feldman 2006, 127) and also for their rarity and exoticness (cf. Helms 1988).

Three materials, all of which were highly valued and considered propitious in ancient Mesopotamia, stand out in particular in the Royal Tombs of Ur for their repeated and very specific use: namely silver, gold (here I include also electrum) and lapis lazuli. Above all, the silver and gold stand out as "the exemplar of vital materiality; it is metal that best reveals this quivering effervescence....bursting with a life' (Bennett 2010, 55), which can be captured into myriad complex forms by a skilled metallurgist, who has intimate knowledge of the material. Considering the vibrancy of the material alongside the enchantment of the object should throw light on how these luxuries were active agents in the embodied consumption of the feast.

Silver was the metal of choice for the elite drinking sets at Ur, as well as at many other contemporary sites in the Near East. This metal - which was probably sourced from the 'Silver Mountains' of Sargonic texts, usually identified with the Taurus mountains (Horowitz $1998,77)$ - was as highly prized as gold in antiquity. The Egyptians for example, identified it with the moon and Thoth, the god of knowledge (Feldman 2006, 118). Tumblers, various different types of bowls, drinking tubes, pouring vessels and side-spouted jars were all 
crafted from this material, which embodied the ideals of ancient value for its lustre, texture and exotic connotations of distance lands. Silver therefore was specifically, and repeatedly, chosen by skilled crafters and/or their patrons for its unique properties, sensuous enchantment and socialized connotations; the metal engaged the viewer/participant and through its metaphysical, allegorical and vital agency was actively engaged in shaping the Mesopotamian feast.

A single electrum (alloy of gold and silver) tumbler in PG800 (see Fig. 10.3) stands out from its sister vessels for its bright gold colour. It presumably was intended to be visually distinctive amongst the set of silver tumblers, perhaps because it belonged to the central figure of the banquet (possibly the deceased, who was considered to be a participant at the feast). Feldman $(2006,118)$ notes the development of very precise terminologies in the Near Eastern text to distinguish between different categories of gold, based upon its brilliance and colour, the latter which would be determined by inclusions of copper or silver, and moreover that this material signified constancy (hurāșu). This then is a significant choice of material, one which would invoke very specific, culturally informed responses on the part of the participants in addition to the more obvious enchantment of a warm-coloured and shiny object. While the shared form of the tumblers, their hidden rosette motif (supra) and exclusive knowledges of how to use this vessel together wove a web of connections and social ties around the participants who drank from them, the distinctive colour and material of the electrum tumbler served to raise one participant above their companion feasters.

An intriguing object from tomb PG779 is the gold cup in the form of an ostrich egg adorned with elaborate inlaid decoration of lapis lazuli, shell and red limestone (Fig. 10.4). Ostrich eggs, transformed into vessels and decorated with inlay, were a surprisingly common elite funerary item in third millennium Sumer, as illustrated by their occurrence in a number of burials at Kish Cemetery A (Torres Rouff 2012, 209, fig. 6). At Ur, these objects tended to be broken into many small fragments, although some complete examples survive (Reade 2003, 119, Cat no. 70b). Ostrich eggs, which were sourced from the deserts of the Near East and Arabian peninsula (Hansen 1998, 70; Moorey 1999, 127), were highly prized as an elite foodstuff for the kings and the gods (Moorey 1999, 128) as much as they were considered suitable as luxurious containers to be included in ritual. As containers and cups they were 
incorporated within rituals in temples - for example as a container of food/drink for the Inanna in her temple at Nippur (Hansen 1998, 71) - and presumably also in ritualized consumption in the tombs. The very precise and delicate replication of an ostrich egg in the most precious of materials - gold (and also silver) and inlay (infra) - reiterates the symbolic value of the form. How exactly the gold ostrich egg was incorporated within embodied feasting practices within the Tomb PG779 remains a matter of debate; for us the importance of the object is the complex entanglement of exotic materials and religious symbolism, and how these combined to give it agency.

\section{$<$ FIGURE 10.4 here $>$}

Other sumptuous equipment from the banquet, such as the lyres and items of personal adornment, although perhaps not directly the material culture of food and drink, certainly contributed to the sensual embodied experiences of the participants. The Great Lyre was brightly decorated with inlay in a colourful mixture of textures and materials - shell, lapis lazuli, silver and gold adorning a wooden frame. The techniques of inlay were particularly highly valued within the shared social milieu of Syro-Mesopotamia, as evidenced by the 'treasures' from Mari (Aruz and Wallenfels 2003, 157-62, Cat nos. 97-104b) and Ebla (Matthiae 2003, 173-7, Cat nos. 112-115f) and continued to be prized into the second millennium (Feldman 2006, 125) and beyond. The lapis lazuli stands out amongst the exotic materials used to adorn the lyre. This was appreciated for its vibrant deep blue colour and the glittering gold pyrite flecks embedded in the substance. As such, the ancient Mesopotamians attributed many symbolic qualities to this stone; it was associated with the night sky, the gods and thus equated with heroic qualities (Feldman 2006, 117). It is interesting to note the luxuriant beard and the tufts of hair of the magnificent bull's head (Hansen 1998, 53, Cat no. 3), since in Mesopotamian texts the colour of lapis was frequently used to describe thick dark locks of hair (Feldman 2006, 117). The lyre, its complex magical imagery (supra) and the choice of materials from which it was crafted exemplify the enchantment of the Mesopotamian feast, through the elaborate interplay of embodied practices, materials and object.

All the objects discussed above define luxury as a special register of consumption (Appadurai 1986, 38). This is evident in their strictly controlled consumption, which marks them out as 
the select paraphernalia of a discrete and exclusive social group. Complex social messages were encoded within each object: the choice of 'vital materials' (cf. Bennett 2010) which invited a response from the participants of the feast, the technological enchantment, the specific form of the object, as well as the requisite esoteric knowledge for appropriate consumption within the embodied actions of the feast. The combination of material, object and iconography coincided and together shaped the material and metaphysical worlds of the Mesopotamian elites. The knowledges, activities and materials embedded in these feasting objects were attractive beyond southern Mesopotamia; we certainly see similar elite items being replicated in the temples and palaces of sites such as Mari and Ebla in Syria, suggesting the development of a shared notion of how to be elite. The spread of this luxurious register of consumption, and presumably also some at least of the appropriate knowledges of how to use these objects, indicate an early development of a shared cultural milieu (Gosden 2003), an exclusive (feasting) club to which the rulers of the region, and their followers, belonged.

\section{CONCLUSIONS}

We have focused here on a discrete group of material, the luxurious feasting objects from the Royal Tombs of Ur and have reconsidered the symbolic and political construction of feasting in the ancient world. Interweaving the physical evidence for the material culture of feasting the eating/drinking vessels, serving equipment and also the objects of entertainment, such as musical instruments - with contemporary depictions of banquets allows us to consider the sensual experience of the feast. This approach brought together two distinct ways in which we might understand elite feasting in early state systems: feasting as political practice with the express intent of to emphasizing and legitimizing exclusivity, power and authority (Dietler 1996) and feasting as a means of creating and reproducing communal memory through embodied action (Hamilakis 1998; 2008; Hamilakis and Sherratt 2012). Exploring these embodied experiences of feast (through object and image) at least allows us a glancing glimpse of these activities and the sense of occasion, which would have been an important and vibrant event for the ancient communities archaeologists study.

We have specifically chosen to engage with the objects of the feast through the lens of enchantment, informed by the burgeoning field of vital materiality (Bennett 2010). Both 
approaches highlight the symbolic, social and ritualized significance of luxurious objects created for high-status consumption and display. Moreover, the concept of vital materiality coincides neatly with the ancient Mesopotamian perspective of the physical properties of matter. Bringing both approaches together, it becomes clear how specific materials and objects were manipulated to enchant the viewer as well as the participant in ancient feasts. The shared embodied knowledges of how to handle these objects, together with the sensorial aspects of the feast and shared registers of value, became widespread throughout Mesopotamia and Syria in the later third millennium BC, ultimately resulting in the creation of what Gosden (2003) terms 'a shared cultural milieu' throughout the region. 


\section{AKCNOWLEDGEMENTS}

Many thanks, as always, to Steve Thomas for reading and commenting on earlier drafts of this paper. Thank you also to members of the Materialities research group in the School of Archaeology, History and Anthropology, UWTSD, for their many stimulating conversations and debates about material culture past and present. Special thanks to Luci Attala and Eloise Govier for our ongoing discussions on vibrant materiality. 


\section{REFERENCES}

André-Salvini, B. (2003) 'Tello (ancient Girsu)', in J. Aruz \& R. Wallenfels (eds) Art of the First Cities: the Third Millennium B.C. from the Mediterranean to the Indus, 68-78. New York, NY, New Haven, CT; London: Metropolitan Museum of Art.

Appadurai, A. (1986) 'Introduction: commodities and the politics of value', in A. Appadurai (ed.) The Social Life of Things Commodities in Cultural Perspective, 3-63. Cambridge: Cambridge University Press.

Aruz, J. \& R. Wallenfels (eds) (2003) Art of the First Cities: the Third Millennium B.C. from the Mediterranean to the Indus, New York, NY, New Haven, CT; London: Metropolitan Museum of Art

Bennett, J. (2010) Vibrant Matter: a Political Ecology of Things. Durham, NC; London: Duke University Press.

Brumfiel, E.M. \& Earle, T.K. (1987) 'Specialization, exchange, and complex societies: an introduction', in E.M. Brumfiel \& T.K. Earle (eds) Specialization, Exchange, and Complex Societies, 1-10. Cambridge: Cambridge University Press.

Cohen, A.C. (2005) Death Rituals, Ideology, and the Development of Early Mesopotamian Kingship: Towards a New Understanding of Iraq's Royal Cemetery of Ur, Leiden; Boston, MA: Brill.

Collon, D. (1992) 'Banquets in the art of the ancient Near East', in R. Gyselen (ed.) Banquets d'Orient, 23-30. (Res Orientales IV) Bures-sur-Yvette: Le Groupe pour l'Étude de la Civilisation du Moyen-Orient.

Connerton, P. (1989) How Societies Remember, Cambridge: Cambridge University Press.

Crawford, H. (1991) Sumer and the Sumerians, Cambridge: Cambridge University Press. (ed.) (2013) The Sumerian World, London; New York, NY: Routledge.

Damerow, P. (1996) 'Food production and social status as documented in Proto-cuneiform texts', in P. Weissner \& W. Schifenhövel (eds) Food and the Status Quest: An Interdisciplinary Perspective,149-69. Providence, RI; Oxford, Berghahn Books. (2012) 'Sumerian beer: the origins of brewing technology in ancient Mesopotamia', Cuneiform Digital Library Journal 2012(2), 1-20. Online: Available HTTP: 
<http://www.cdli.ucla.edu/pubs/cdlj/2012/cdlj2012_002.html> (accessed March 2016).

Dietler, M. (1996) 'Feasts and commensal politics in the political economy: food, power, and status in prehistoric Europe', in P. Weissner \& W. Schifenhövel (eds) Food and the Status Quest: An Interdisciplinary Perspective, 87-125. Providence, RI; Oxford, Berghahn Books.

(2001) 'Theorizing the feast: rituals of consumption, commensal politics, and power in African contexts', in M. Dietler \& B. Hayden (eds) Feasts: Archaeological and Ethnographic Perspectives on Food, Politics, and Power, 65-114. Washington DC; London Smithsonian Institute.

Feldman, M.H. (2006) Diplomacy by Design: Luxury Arts and an "international Style” in the Ancient Near East, 1400-1200 BCE, Chicago, Il: University of Chicago Press.

Gell, A. (1992) 'Technology of enchantment and the enchantment of technology', in J. Cootes, J. \& A. Shelton (eds) Anthropology, Art and Aesthetics, 40-63. Oxford: Clarendon.

Gosden, C. (2003) Archaeology and Colonialism. Cultural Contact from 5000 BC to the Present, Cambridge: Cambridge University Press.

Hamilakis, Y. (1998) 'Eating the dead: mortuary feasting and the politics of memory in the Aegean Bronze Age societies', in K. Branigan (ed.) Cemetery and Socieyt in thee Aeegan Bronze Age, 115-32. Sheffield: University Of Sheffield Press. (2008) 'Time, performance, and the production of a mnemonic record: from feasting to an archaeology of eating and drinking', in L. Hitchcock, R. Laffineur \& J. Crowley (eds) DAIS: The Aegean Feast (Proceedings of the 12th International Aegean Conference, 25-29 March 2008, The University of Melbourne (Aegaeum 29), 3-19. Liège; Austin, TX: Université de Liège \& University of Texas at Austin Hamilakis, Y. \& S. Sherratt (2012) 'Feasting and the consuming body in Bronze Age Crete and Early Iron Age Cyprus', in Parallel Lives: Ancient Island Societies in Crete and Cyprus, G. Cadogan, M. Iacovou, K. Kopaka and J. Whitley (eds), 187-207. London: British School at Athens. 
Hansen, D.P (1998) 'Art of the Royal Tombs of Ur: a brief interpretation', in R.L. Zettler, \& L. Horne (eds) Treasures from the Royal Tombs of Ur, 43-72. Philadelphia, PA: University of Pennsylvania Museum of Archaeology and Anthropology

Hayden, B. (2014) The Power of Feasts: From Prehistory to the Present, Cambridge: Cambridge University Press Helms, M.W. (1993) Craft and the Kingly Ideal: Art, Trade, and Power, Austin, TX: University of Texas Press.

Helms, M.W. (1988) Ulysses' Sail: An Ethnographic Odyssey of Power, Knowledge, and Geographical Distance, Princeton, NJ: Princeton University Press. (1993) Craft and the Kingly Ideal: Art, Trade, and Power, Austin, TX: University of Texas Press.

Horowitz, W. (1998) Mesopotamian Cosmic Geography, Winona Lake, IN: Eisenbrauns. MacDougal, R. (2014) Remembrance and the Dead in Second Millennium BC Mesopotamia. Unpublished Ph.D thesis, University of Leicester.

Matthiae, P. (2003) 'Ebla and the Early Urbanization of Syria', in J. Aruz \& R. Wallenfels (eds) Art of the First Cities: the Third Millennium B.C. from the Mediterranean to the Indus, 165-78. New York, NY, New Haven, CT; London: Metropolitan Museum of Art

Mauss, M. (1925) Essai sur le Don; trans. W.D. Halls (1990) The Gift: The Form and Reason for Exchange in Archaic Societies, New York, NY; London: W.W. Norton.

McGovern, P.E. (2009) Uncorking the Past: The Quest for Wine, Beer, and Other Alcoholic Beverges, Berkeley, CA: University of California Press.

Moorey, P.R.S. (1999) Ancient Mesopotamian Materials and Industries: the Archaeological Evidence, Winona Lake, IN: Esienbrauns.

Oriental Institute (1997.) 'The debate between winter and summer', The Electronic Text Corpus of Sumerian Literature, Oriental Institute: Oxford. Online. Available HTTP: $<$ http://etcsl.orinst.ox.ac.uk/section5/tr533.htm> (accessed February 2016).

Pinnock, F. (1994) 'Considerations on the "Banquet Theme" in the figurative art of Mesopotamia and Syria, in L. Milano (ed.) Drinking in Ancient Societies, 15-26. Padova: Sargon. 
Pittman, H. (1998) 'Jewelry', in R.L. Zettler, \& L. Horne (eds) Treasures from the Royal Tombs of Ur, 87-122. Philadelphia, PA: University of Pennsylvania Museum of Archaeology and Anthropology

Pollock, S. (1991) 'Of priestesses, princes, and poor relations: the dead in the Royal Cemetery of Ur', Cambridge Archaeological Journal 1(2): 171-89. (1999) Ancient Mesopotamia: the Eden that Never Was, Cambridge: Cambridge University Press. (2003) 'Feasts, funerals and fast foods in Early Mesopotamian states', in T.L. Bray (ed.) The Archaeology and Politics of Food and Feasting in Early States and Empires, 17-38, New York, NY: Kluwer Academic; Plenum Publishers. (2007) 'Death of a household', in N. Laneri (ed.) Performing Death: Social Analyses of Funerary Traditions in The Ancient Near East and Mediterranean, Oriental Institute Seminars No. 3, 209-22. Chicago, IL: University of Chicago. (2007a) 'The Royal Cemetery of Ur: ritual, tradition, and the creation of subjects', in M. Heinz \& M.H. Feldman (eds) Representations of Political Power: Case Histories from Times of Change and Dissolving Ordrer in the Ancient Near East, 89110.

Postgate, N. (1994) Early Mesopotamia: Society and Economy at the Dawn of History, London: Routledge.

Reade, J. (2003) 'The Royal Tombs of Ur', in J. Aruz \& R. Wallenfels (eds) Art of the First Cities: the Third Millennium B.C. from the Mediterranean to the Indus, 93-132. New York, NY, New Haven, CT; London: Metropolitan Museum of Art.

Schmandt-Besserat, D. (2001) 'Feasting in the ancient Near East', in M. Dietler \& B. Hayden (eds) Feasts: Archaeological and Ethnographic Perspectives on Food, Politics, and Power, 391-403. Washington DC; London Smithsonian Institute.

Schwartz, G.M. (2007) 'Status, ideology and memory in third-millennium Syria: "Royal” tombs at Umm el-Marra' in N. Laneri (ed.) Performing Death: Social Analyses of Funerary Traditions in The Ancient Near East and Mediterranean, Oriental Institute Seminars No. 3, 39-68. Chicago, Il: University of Chicago.

Spielman, K.A. (2002) 'Feasting, craft specialization, and the ritual mode of production in small-scale societies', American Anthropologist (n.s) 104(1): 195-207. 
Steel, L. (2004) 'A goodly feast... a cup of mellow wine: feasting in Bronze Age Cyprus', in J.C. Wright (ed) The Mycenaean Feast, 161-80. Princeton, NJ: American School of Classical Studies at Athens.

(2013) Materiality and Consumption in the Bronze Age Mediterranean, New York, NY, London: Routledge.

Stockhammer, P.W. (2012) 'Performing the practice turn in archaeology', Transcultural Studies 1: 7-42. Online. Available HTTP: < http://heiup.uniheidelberg.de/journals/index.php/transcultural/article/view/9263> (accessed January 2016).

Strommenger, E. (1962) Fuenftausend Jahre Mesopotamien, Munich: Hirmer Verlag.

Torres-Rouff, C. (2012) 'Commemorating bodies and lives at Kish’s 'A cemetery': (re)presenting social memory', Journal of Social Archaeology 12(2) 193-219.

Weber, J.A. \& R.L. Zettler (1998) 'Metal vessels', in R.L. Zettler, \& L. Horne (eds) Treasures from the Royal Tombs of Ur, 125-40 . Philadelphia, PA: University of Pennsylvania Museum of Archaeology and Anthropology. (1998a) 'Tools and weapons', in R.L. Zettler, \& L. Horne (eds) Treasures from the Royal Tombs of Ur, 163-73. Philadelphia, PA: University of Pennsylvania Museum of Archaeology and Anthropology.

Winter, I.J. (1995) 'Aesthetics in ancient Mesopotamian art', in J.M. Sasson (ed.) Civilisations of the Ancient Near East, 2569-80. Peabody, MA: Hendrickson.

Zettler, R.L. (1998) ‘The burials of a king and queen', in R.L. Zettler, \& L. Horne (eds) Treasures from the Royal Tombs of Ur, 33-8. Philadelphia, PA: University of Pennsylvania Museum of Archaeology and Anthropology.

(1998a) 'Stone vessels', in R.L. Zettler, \& L. Horne (eds) Treasures from the Royal Tombs of Ur, 149-60. Philadelphia, PA: University of Pennsylvania Museum of Archaeology and Anthropology. 


\section{NOTES}

${ }^{1}$ For more detailed discussion of the archaeological and historical context of Early Dynastic Mesopotamia see Crawford 1991; 2013; Postgate 1994; Pollock 1999. For more information specifically on the Royal Tombs at Ur see Pollock 1991; Cohen 2005; Pollock 2007; 2007a.

${ }^{2}$ An in-depth analysis of the rosette motif in the ancient Near East, Aegean and Egypt is currently being undertaken by Cheryl Hart for her PhD thesis at University of Wales Trinity Saint David. I am grateful to Cheryl for drawing my attention to this specific use of the rosette at Ur and highlighting a number of parallels on other elite drinking equipment throughout the wider region in the second and first millennium BC. 